\title{
Distribution of Fruit Fly (Diptera, Tephritidae, Anastrepha) in Anthropized Areas of Cerrado, Western Bahia, Brazil ${ }^{\dagger}$
}

\author{
Tayron Sousa Amaral 1,*, Rodrigo de Souza Bulhões ${ }^{2}$, Valdeir Pereira Lima ${ }^{3}$, Ana Elizabete Lopes Ribeiro ${ }^{4}$ and \\ Daniéla Cristina Calado ${ }^{1}$
}

Citation: Amaral, T.S.; de Souza

Bulhões, R.; Lima, V.P.; Ribeiro,

A.E.L.; Calado, D.C. Distribution of fruit fly (Diptera, Tephritidae, Anastrepha) in anthropized areas of Cerrado, Western Bahia, Brazil, in Proceedings of the 1st International Electronic Conference on Entomology, 1-15 July 2021, MDPI: Basel, Switzerland,

Published: 1 July 2021

Publisher's Note: MDPI stays neutral with regard to jurisdictional claims in published maps and institutional affiliations.

Copyright: (c) 2021 by the authors. Submitted for possible open access publication under the terms and conditions of the Creative Commons Attribution (CC BY) license (http://creativecommons.org/licenses /by/4.0/).
1 Center of Biological and Health Sciences, Federal University of Western Bahia (UFOB), Barreiras, Bahia, Brazil; tayron.amaral@gmail.com

2 Department of Statistics, Federal University of Bahia (UFBA), Salvador, Bahia, Brazil.

3 Department of Plant Sciences, Federal University of Santa Catarina (UFSC), Florianópolis, Santa Catarina, Brazil.

4 Center of Multidisciplinary Studies, Federal University of Western Bahia (UFOB), Barra, Bahia, Brazil.

* Correspondence: tayron.amaral@gmail.com

† Presented at the 1st International Electronic Conference on Entomology (IECE 2021), 1-15 July 2021; Available online: https://iece.sciforum.net/.

\begin{abstract}
We evaluate the occurrence of Anastrepha in three areas with different anthropization levels: guava monoculture, polyculture, and native forest in the municipality of Barreiras, Bahia, Brazil. We collected the occurrence data using thirty McPhail traps, which were evenly distributed in the areas. Fifteen collections were carried out weekly between January and May 2021. We observed a significant difference in means of Anastrepha occurrence between the polyculture area $(4.133 \pm 1.586)$ and the other areas. Regarding the area of monoculture of guava $(1.286 \pm 0.663)$ and the native forest $(0.740 \pm 0.283)$, we observed no significant differences.
\end{abstract}

Keywords: Cerrado biome; fruit flies; monoculture; polyculture

\section{Introduction}

Fruit flies are of great economic importance worldwide, having as their main representative species of the Tephritidae family [1,2]. These insects are primary pests in preharvest, attacking the fruits in the field $[3,4]$. In the western region of Bahia, Brazil, government support for agricultural activities boosted the region's growth and colonization from the mid-1970s [5]. Currently, this region has great prominence in the Brazilian scenario regarding the production of soybean, corn, cotton and coffee. Irrigated perimeters supplied with the Rio Grande Basin are predominantly used for the production of banana, mango, citrus, papaya, cocoa and passion fruit, grown on small properties and destined for the local market [6].

The production and commercialization of fruits in the most varied regions face several phytosanitary problems. Fruit flies limit production and marketing, especially in foreign trade, as several countries impose quarantine barriers to the introduction of fruits from countries where these insects are present [7]. In some regions, fruit flies can also limit the production of other crops such as the trade of native fruits, impacting the local economy [8].

Among tephritids, the genus Anastrepha originates from the Americas, occurring in South America (except Chile), Central America and the southern region of the United States [9]. Currently, around 300 species infest a large number of native and exotic hosts [8, 10]. In Brazil, 121 species of Anastrepha have been recorded in more than 275 hosts of 48 native and exotic plant families until 2021 [8]. 
Although several studies show the diversity of frugivorous flies in native and cultivated areas of the Brazilian Cerrado [e.g., 11, 12], information about its occurrence in western Bahia, one of the main agricultural frontiers in Brazil, is scarce. Here, we evaluate the occurrence of Anastrepha in three areas with different anthropization levels: (1) guava monoculture, (2) polyculture, and (3) native forest in the municipality of Barreiras, Bahia, Brazil.

\section{Methods}

\subsection{Study Area}

Fifteen collections were carried out weekly between January and May 2021 in three areas with different anthropization levels: (1) guava monoculture (12 $19^{\prime} 03.95^{\prime \prime S}$, $\left.45^{\circ} 00^{\prime} 47.29^{\prime \prime O}\right)$, (2) polyculture $\left(12^{\circ} 18^{\prime \prime}\right.$ ' $\left.11.55^{\prime \prime S}, 45^{\circ} 00^{\prime} 52.02 " \mathrm{O}\right)$, and (3) native forest $\left(12^{\circ} 08^{\prime} 49.22^{\prime \prime} \mathrm{S}, 45^{\circ} 01^{\prime} 15.69^{\prime \prime} \mathrm{O}\right)$ in the municipality of Barreiras, Bahia, Brazil.

\subsection{Anastrepha Species Collection and Identification}

We collected the occurrence data using thirty McPhail traps, which were evenly distributed in the areas and supplied with the attractive CeraTrap ${ }^{\circledR}$ food. Fifteen collections were carried out weekly between January and May 2021. Then, after removing the insects from the traps, they were transported to the laboratory for screening and identification of the genus based on morphological characters.

\subsection{Data Analysis}

First, we checked the normality of the data using the Shapiro-Wilk test. Then, to compare the occurrences of Anastrepha in the three different areas, we applied the KruskalWallis test and the Bonferroni multiple comparison test $(\alpha=0.05)$. All statistical procedures were performed using $\mathrm{R}$ programming

\section{Results}

We found a total of 924 specimens of Anastrepha, 620 in the polyculture area, 193 in the guava monoculture and 111 specimens in the native forest. We observed the largest amounts of individuals in the collections 1, 2, 8, 6 and 5 in the polyculture area between January and March. Additionally, we observed a reduction for April and May. For the guava area, we observed the highest rates between April and May in the collections 12, $14,11,13$ and 15 and for the native forest area in the collections $3,10,11,4$ and 5 (Table 1).

Table 1. Specimens of Anastrepha (Diptera, Tephritidae) collected between January and May 2021 using Mcphail traps in three different anthropogenic areas in the municipality of Barreiras, Bahia, Brazil.

\begin{tabular}{|c|c|c|c|c|c|c|c|c|c|c|c|c|c|c|c|c|}
\hline \multirow{2}{*}{ Area } & \multicolumn{15}{|c|}{ Collections } & \multirow{2}{*}{ Total } \\
\hline & 1 & 2 & 3 & 4 & 5 & 6 & 7 & 8 & 9 & 10 & 11 & 12 & 13 & 14 & 15 & \\
\hline $\begin{array}{c}\text { Guava } \\
\text { monoculture }\end{array}$ & 1 & 0 & 1 & 2 & 6 & 3 & 3 & 11 & 13 & 15 & 26 & 33 & 25 & 33 & 21 & 193 \\
\hline Polyculture & 95 & 90 & 18 & 37 & 39 & 70 & 57 & 71 & 31 & 26 & 32 & 22 & 19 & 8 & 5 & 620 \\
\hline Native forest & 2 & 6 & 16 & 11 & 11 & 5 & 2 & 8 & 10 & 15 & 14 & 4 & 1 & 3 & 3 & 111 \\
\hline Total & 98 & 96 & 35 & 50 & 56 & 78 & 62 & 90 & 54 & 56 & 72 & 59 & 45 & 44 & 29 & 924 \\
\hline
\end{tabular}

We observed a statistically significant difference in the occurrence of Anastrepha between the polyculture area $(4,133 \pm 1,586)$ and the other studied areas (Table 2$)$. However, the areas of guava monoculture $(1,286 \pm 0.663)$ and native forest $(0.740 \pm 0.283)$ had no statistically significant difference (Figure 1$)$. 
Table 2. Bonferroni's test for multiple comparisons of means at $95 \%$ confidence.

\begin{tabular}{cccc}
\hline Pairs & Difference & 95\% CI & $p$-value \\
\hline Polyculture vs. Guava & 2.84666667 & $(1.191680,4.501653)$ & 0.00031 \\
Native forest vs. Guava & -0.5466667 & $(-2.201653,1.108320)$ & 1.00000 \\
Native forest vs. Polyculture & -3.3933333 & $(-5.048320,-1.738347)$ & $2.2 \times 10^{-5}$ \\
\hline \multirow{3}{*}{ CI: Confidence interval. } \\
\hline
\end{tabular}

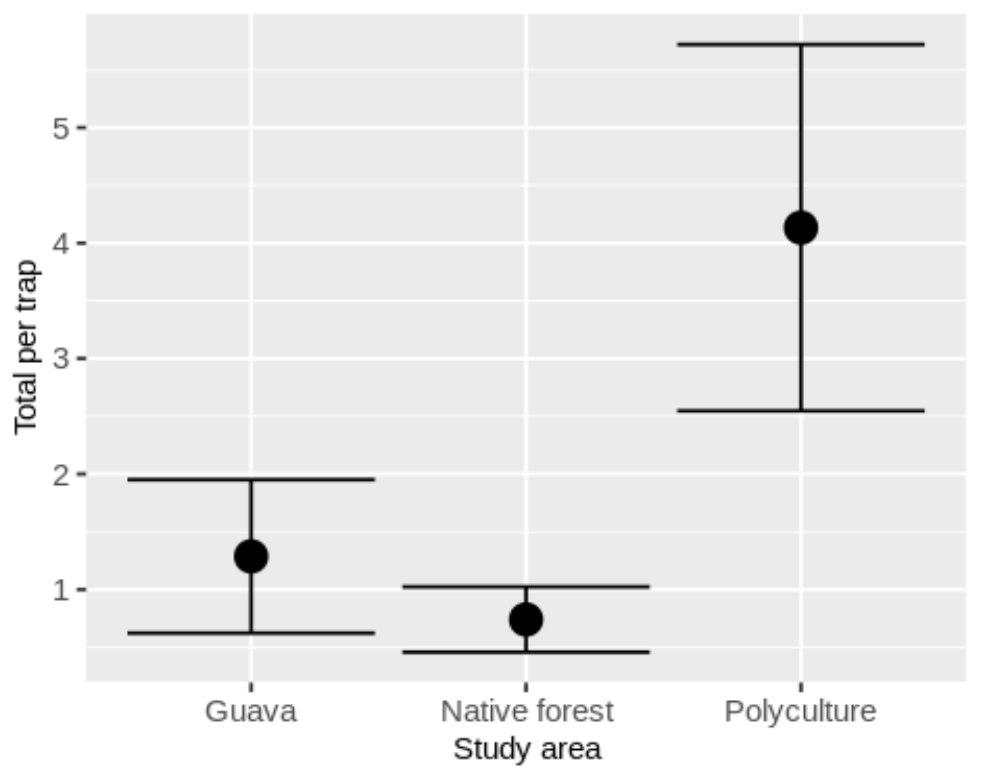

Figure 1. Point and interval estimations at 95\% confidence level for specimens of Anastrepha (Diptera, Tephritidae) collected between January and May 2021 using Mcphail traps in three different anthropogenic areas in the municipality of Barreiras, Bahia, Brazil.

\section{Discussion}

Our study shows that the largest amounts of Anastrepha are in the polyculture area, where several crops such as mango (Mangifera indica L.), acerola (Malpighia emarginata DC.), grape (Vitis vinifera L.), guava (Psidium guajava L.) and cashew (Anacardium occidentale L.) can be found. The collection period coincided with the end of mango and guava production, which had fruits on the plant during part of the collections. Acerola fruits were present in the field throughout the collected period and there were no grapefruits on the property. The presence of fruits found in the field can be a determining factor for obtaining this higher occurrence rate. Further, the lack of control of these insects may explain the population growth of Anastrepha [13].

Furthermore, the largest amounts of Anastrepha can also be attributed to the large number of possible hosts present in the area, in addition to the species' preference for specific hosts, which were not present in the other areas. The maintenance of Anastrepha fraterculus (Wiedemann, 1830) (the most common species in Brazil) can be favored through the great host diversity, thus allowing field populations to remain at high levels [14].

No significant differences were observed between the native forest area and the guava monoculture. Despite the large availability of fruits present in guava monoculture, the incidence of Anastrepha was lower when compared to the polyculture area. Throughout the collections, management practices were verified in the cultivation of the guava such as the removal of fallen fruits from the area, removal of invasive plant species and periodic pruning. These practices can have a negative impact on fruit fly populations by reducing the number of flies present or favoring species migrations [13]. In the native forest area, no host plants were found in the surroundings, which may explain the low 
incidence of these insects when compared to those with the cultivation of fruit trees such as mango, acerola, cashew and orange.

The municipality of Barreiras has a high incidence of Anastrepha in polyculture areas, while in areas of native forest and guava monoculture the incidence seems to be lower. Thus, in order to carry out a more accurate diagnosis of the occurrence of these insects in the western region of Bahia, as well as the impact on regional fruit production, it is necessary to identify these species and monitor them for a long time.

\section{Acknowledgements: FAPESB; UFOB.}

\section{References}

1. ALUJA, M.; MANGAN, R. L. Fruit fly (Diptera: Tephritidae) host status determination: critical conceptual, methodological, and regulatory considerations. Annu. Rev. Entomol. 2008, 53, 473-502.

2. UCHOA, M. A. Fruit flies (Diptera: Tephritoidea): biology, host plants, natural enemies, and the implications to their natural control. In Integrated Pest Management and Pest Control: Current and Future Tactics. Larramendy, M.L., Soloneski, S. (Eds.). Rijeka: Intech. 2012. p. 271-300.

3. MALAVASI, A. et al. Biogeografia. In Moscas-das-frutas de importância econômica no Brasil: conhecimento básico e aplicado. MALAVASI, A.; ZUCCHI, R.A. (Ed.). Ribeirão Preto: Holos, 2000. p. 93-98.

4. ALVARENGA, C.D. et al. Alternativas no controle de moscas-das-frutas. In Tecnologias alternativas para o controle de pragas e doenças. VENZON, M.; PAULA JÚNIOR, T. J.; PALLINI, A.L. (Eds.). Viçosa: EPAMIG, 2006. p. 227-252.

5. CODEVASF - Companhia de Desenvolvimento dos Vales do São Francisco e do Parnaíba. Perímetros irrigados São Desidério/Barreiras Sul. 2018. Available online: http://www.codevasf.gov.br/principal/\%20perimetros-irrigados/elenco-de-projetos/sao-desiderio-barreiras-sul. Accessed on 10 March 2021.

6. SEI - Superintendência de Estudos Econômicos e Sociais da Bahia. Uso atual das terras: Bacia do Rio Grande, Bahia. SEI, Salvador, 2019. p. 248.

7. DUARTE, A.L.; MALAVASI, A. Tratamentos quarentenários In Moscas-das-frutas de importância econômica no Brasil: conhecimento básico e aplicado. MALAVASI, A.; ZUCCHI, R.A. (Ed.). Ribeirão Preto: Holos, 2000, 187-192.

8. ZUCCHI, R. A; MORAES, R. C. B. Moscas-das-frutas no Brasil: espécies de Anastrepha suas plantas hospedeiras e parasitoides. 2008. Available online: Disponível em: www.lea.esalq.usp.br/anastrepha/. Accessed on 20 April 2020.

9. ZUCCHI, R.A. Taxonomia. In Moscas-das-frutas de importância econômica no Brasil: conhecimento básico e aplicado. MALAVASI, A.; ZUCCHI, R.A. (Ed.). Ribeirão Preto: Holos, 2000. p. 13-24.

10. NORRBOM, A.L. et al. Novas espécies e plantas hospedeiras de Anastrepha (Diptera: Tephritidae) principalmente do Peru e da Bolívia. ZooTaxa 2015, 4041, 1-94.

11. UCHÔA-FERNANDES M.A. et al. Species Diversity of Frugivorous Flies (Diptera: Tephritoidea) from Hosts in the Cerrado of the State of Mato Grosso do Sul, Brazil. Neotrop. Entomol. 2002, 31, 515-524.

12. VELOSO, V.R.S. et al. Moscas-das-frutas (Diptera, Tephritidae) no Estado de Goiás: ocorrência e distribuição. Pesqui. Agropecu. Trop. 2012, 42, 357-367.

13. NAVA. D.E.; BOTTON, M. Bioecologia e Controle de Anastrepha fraterculus e Ceratitis capitata em Pessegueiro. EMBRAPA: Clima Temperado. Documentos, 316. Pelotas, RS. 2010. p. 29.

14. SALLES, L. A. B. Biologia e ciclo de vida de Anastrepha fraterculus (Wied.). In Moscas-das-frutas de importância econômica no Brasil: conhecimento básico e aplicado. MALAVASI, A.; ZUCCHI, R.A. (Ed.). Ribeirão Preto: Holos, 2000. p. 81-86. 